Vovk M. V.

Estimation of methods of the field research of the birds' activities forming the environment

УДК 598.2 : 581.524

М. В. Вовк

Дніпропетровський національний університет

\title{
АНАЛІЗ МЕТОДИК ДОСЛІДЖЕННЯ СЕРЕДОВИЩЕТВІРНОЇ АКТИВНОСТІ ПТАХІВ
}

Проаналізовано методики, використання яких доцільне при дослідженні колоніальних поселень птахів. На прикладі сірої чаплі описано методики вивчення просторової структури популяції та її впливу на біогеоценоз. Запропоновано методики, оптимальні для проведення комплексних зооекологічних досліджень.

The paper is devoted to the different methods of the field research of the birds' colonies. By the example of common heron the assessment methods of spatial structure of the population and its influence on a biogeocoenosis are described. Most acceptable and available techniques are proposed.

\section{Вступ}

При вивченні колоніальних поселень птахів використано багато методик, що дозволяють простежити закономірності біологічних процесів [3; 6; 7; 12]. Біологія птахів належить до тієї галузі знань, до якої істотний внесок можуть вносити й аматори.

(C) М. В. Вовк, 2007

20

Вісник Дніпропетровського університету. Біологія, екологія.

Vìsnik Dnìpropetrovs'kogo unìversitetu. Serìa Bìologîa, ekologîâ

Visnyk of Dnipropetrovsk University. Biology, ecology. Vìsn. Dnìpropetr. Unìv. Ser. Bìol. Ekol. 2007. 15(1).

ISSN 2310-0842 print ISSN 2312-301X online www.ecology.dp.ua 
У наш час птахи цінуються як експериментальні тварини для вивчення розмноження, розвитку, поведінки, живлення, гормональних механізмів, спадковості та росту пухлин; вони важливі також для досліджень в галузі екології та сільського господарства [11]. Раніше вивченням і обліком птахів займалися лише спеціалісти-орнітологи, однак у наш час орнітофауна привертає увагу органів охорони здоров'я [10].

Середовищетвірна активність птахів має комплексний характер. Методи опосередкованої оцінки потребують застосування багатьох методик різних галузей біології (грунтознавства, зоології, ботаніки). Враховуючи високий рівень складності реалізації різних методик на одній площі у стислі строки, необхідно обирати ті варіанти методик, які можуть дати найкращі результати при мінімальних часових витратах. Середовищетвірна діяльність чапель може докорінно вплинути на процеси грунтоутворення, вигляд біогеоценозу. Вона призводить до прискорених зоогенних сукцесій.

Мета даної роботи - узагальнення основних методик досліджень колонії сірої чаплі (Ardea cinerea L.).

\section{Матеріал і методи досліджень}

Систематичні дослідження проводили на території Дніпровсько-Орільського природного заповідника у 2000-2003 роках. Дендрофлора району досліджень характеризується домінуванням в’яза (Ulmus laevis L.), тополі чорної (Populus nigra L.) та дуба звичайного (Quercus robur L.). Верхній ярус деревостану складають тополя та дуб, середній - переважно в'яз. Кущовий ярус представлений аморфою (Amorpha fruticosa L.). Більшість тополь та дубів представлені особинами у віковому стані $\mathrm{g}_{2}$ та $\mathrm{g}_{3}$. У ході досліджень ми намагалися визначити вимоги сірої чаплі до місць гніздування. Для цього використано методику, запропоновану О. В. Міхеєвим [8].

Вивчення конструкції гнізда, його будівельного матеріалу, способу прикріплення гнізда до опори, характеру опори допомагає уявити форми взаємозв'язків організму та середовища [8]. Встановлено три типові позиції гнізд: 1) у розвилці головного стовбура, 2) біля стовбура, в місцях відходження бічних гілок, 3) на бічних гілках (рис. 1).
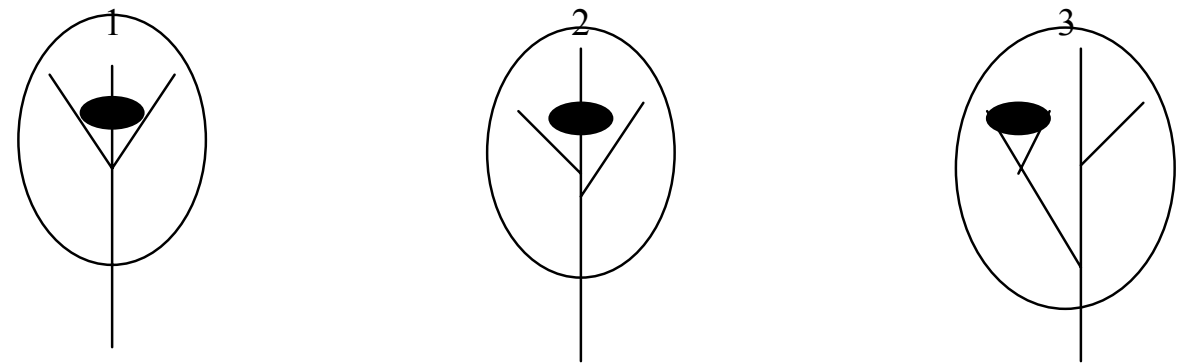

Рис. 1. Типи розташування гнізд: I - у розвилці головного стовбура; 2 - біля стовбура, в місцях відходження бічних гілок; 3 - на бічних гілках

В основу опису місцеперебувань чапель покладена загальноприйнята типологія штучних і природних лісів степової зони України, розроблена О. Л. Бельгардом [1].

Для визначення впливу екскреторної діяльності чапель на накопичення у грунті комплексу NPK використано наступну методику. Грунтові зразки для хімічного аналізу відбирали в місцях інтенсивного впливу екскрецій та на контрольних ділянках із п'яти грунтових горизонтів $(0-10,10-20,20-30,30-40$ та 40-50 см) на відстані 2 м одна від одної у трьох напрямках.

Вісник Дніпропетровського університету. Біологія, екологія.

Vìsnik Dnìpropetrovs'kogo unìversitetu. Serìa Bìologîa, ekologîâ Visnyk of Dnipropetrovsk University. Biology, ecology. Vìsn. Dnìpropetr. Unìv. Ser. Bìol. Ekol. 2007. 15(1).

ISSN 2310-0842 print ISSN 2312-301X online www.ecology.dp.ua 


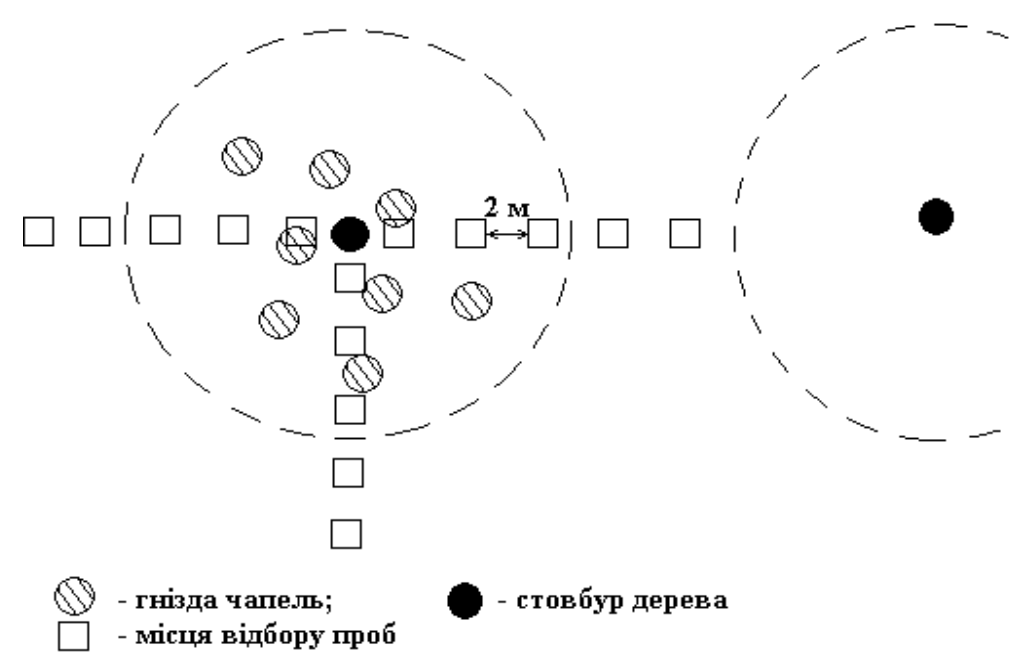

Рис. 2. Схема розташування місць відбору проб

Відібрані проби грунту висушували у сушильній шафі до абсолютно сухого стану протягом 48 годин при температурі $+105 \ldots+160^{\circ} \mathrm{C}$. Просушені грунтові зразки розтирали у ступці, видаляли сторонні включення. Визначення вмісту комплексу $N P K$ здійснювали за методичними вказівками щодо проведення агрохімічних аналізів грунту та рослин [14]. Таким чином було отримано дані щодо впливу азоту, фосфору та калію на грунтовий покрив [4]. Для визначення вмісту важких металів у грунті використовували стандартну методику атомно-адсорбційної спектрофотометрії на спектрофотометрі AAS 30 [9]. Схема добору грунтових проб та показники відносної ефективності наведені у попередніх роботах [5].

Дослідження просторової структури популяції Ardea cinerea L. здійснювали шляхом систематичних візуальних спостережень на території колонії.

\section{Результати та їх обговорення}

Рослинний покрив будь-якої місцевості обумовлений флористично, екологічно та історично [13]. Режим місцеперебувань визначає склад рослинності не прямо, а через складну взаємодію членів рослинного покриву. Ценоз - екологічно обумовлене територіально однорідне угруповання рослинності або сукупність подібних угруповань, близькість яких обумовлена екологічно та флористично [13].

Загальноприйнятною є пробна площа в 0,25 га; на луках й у степу - 0,01 га (дані доповнюються та коригуються вивченням навколишньої території). Тільки аналіз суцільної та достатньо великої пробної площі дозволить отримати повну характеристику рослинності [13].

Стаціонарні дослідження являють собою особливий тип геоботанічних робіт. Вони здійснюються на невеликих площах й охоплюють спеціально відібрані та типові для даної території фітоценози. Важливою особливістю стаціонарних робіт, при значному різноманітті завдань, $є$ те, що вони встановлюють найтісніші зв'язки між рослинним покривом і середовищем існування не тільки в статичному, а й у динамічному плані. Рослинний покрив ретельно аналізується за віковими групами, структурою, розміщенням [15].

Облік птахів у колонії сірої чаплі проведено методом списків Маккінона [2]. Складання списків Маккінона - один із способів розрахунку кривих виявлення та індексів відносної рясності видів. Цей метод пов'язаний із здібностями окремих спостерігачів. Суть його полягає у складанні спостерігачем списку видів до тих пір,

Вісник Дніпропетровського університету. Біологія, екологія.

Vìsnik Dnìpropetrovs'kogo unìversitetu. Serìa Bìologîa, ekologîâ Visnyk of Dnipropetrovsk University. Biology, ecology. Vìsn. Dnìpropetr. Unìv. Ser. Bìol. Ekol. 2007. 15(1).

ISSN 2310-0842 print ISSN 2312-301X online www.ecology.dp.ua 
поки він не досягне певного розміру. У кожному списку вид може бути зареєстрований лише один раз. У нових списках цей вид може бути відмічений знов. Довжина списків складає від 8 до 20 видів. Чим вірогідніше загальне видове багатство того чи іншого місця перебування, тим довшим має бути стандартний список. Спостереження продовжуються до того часу, поки не будуть складені мінімум 10 списків із понад 15 видами для кожного угіддя. При роботі необхідно намагатися максимально широко охопити територію, для того, щоб одні й ті самі види не потрапляли до повторних списків [2].

Для теріологічних досліджень використано методику, запропоновану Кучеруком зі співавторами [11]. Ї̈̈ суть полягає у використанні облікових ліній, які складають 25 пасток. Переваги ліній такого розміру наступні. Один спостерігач може щоденно виставляти пастки на 6-8 облікових лініях, обстежуючи значну площу й охоплюючи обліком одночасно декілька біотопів; за короткий термін він отримує велику кількість проб, що дозволяє статистично обробити облікові дані [11]. Остаточні дані щодо чисельності мишоподібних гризунів обробляються.

У більшій частині інструкцій з обліку чисельності дрібних ссавців рекомендується ставити пастки на облікових лініях через 5 м. Збільшення цієї відстані до $10 \mathrm{~m}$ не призводить до істотного підвищення ефективності облікової лінії, тому доцільно зберегти відстань між пастками 5 м та вважати ії обов'язковим стандартом [11].

\section{Висновки}

Сформовано схему проведення польових досліджень, яку доцільно використовувати при вивченні екскреторної активності чапель: проведення орнітологічних досліджень методом Маккінона, визначення чисельності мишоподібних гризунів, вивчення рослинності методом, запропонованим Л. Г. Раменським, дослідження грунту на наявність важких металів та комплексу NPK.

\section{Бібліографічні посилання}

1. Бельгард А. Л. Степное лесоведение. - М.: Лесная промышленность, 1971. - 336 с.

2. Бибби К. Методы полевых экспедиционных исследований. Исследования и учеты птиц / К. Бибби, М. Джонс, С. Марсден. - М.: Союз охраны птиц России, 2000. - 186 с.

3. Булахов В. Л. Об орнитофауне среднего Днепра в районе строительства будущего Днепродзержинского водохранилища // Материалы 3-й Всесоюз. орнитолог. конф. - Львов, 1962. - T. 1. - С. 46-48.

4. Вовк М. В. Роль колониальных поселений цапель в формировании комплексов NPK в почвенных покровах Днепровско-Орельского природного заповедника // Проблемы экологии и охраны природы техногенного региона. - Вып. 4. - Донецк: ДонНУ, 2004. C. $97-101$.

5. Вовк М. В. Вплив колоніальних поселень чапель на накопичення важких металів у грунтовому покриві Дніпровсько-Орільського природного заповідника // Вісник Дніпропетровського університету. Біологія. Екологія. - Д.: ДНУ, 2005. - Вип. 3, т. 1. - С. 19-21.

6. Губкин А. А. Орнитофауна как структурный компонент лесных биогеоценозов степной зоны юго-востока Украины. Дис. ... канд. биол. наук. - Д.: ДГУ, 1971. - 221 с.

7. Гулай В. И. Экологическая характеристика водно-болотных птиц западной лесостепи Украины. - Львов, 1980. - 199 с.

8. Михеев А. В. Определитель птичьих гнезд. - М.: Просвещение, 1975. - 175 с.

9. Морозов Н. П. Микроэлементы в промысловой ихтиофауне мирового океана / Н. П. Морозов, С. А. Петухов. - М.: Агропромиздат, 1986. - 158 с.

10. Мясоедова О. М. Формирование орнитофауны Ленинского водохранилища: Дис. ... канд. биол. наук. - Д.: ДГУ, 1971. - 252 с.

11. Организация и методы учета птиц и вредных грызунов. - М.: АН СССР, 1963. - 256 с.

Вісник Дніпропетровського університету. Біологія, екологія.

Vìsnik Dnìpropetrovs'kogo unìversitetu. Serìâ Bìologîâ, ekologiâ Visnyk of Dnipropetrovsk University. Biology, ecology. Vìsn. Dnìpropetr. Unìv. Ser. Bìol. Ekol. 2007. 15(1).

ISSN 2310-0842 print ISSN 2312-301X online www.ecology.dp.ua 
Vovk M. V.

Estimation of methods of the field research of the birds' activities forming the environment

12. Птицы / К. Уэлти, Д. Сторер, К. Пенникуик и др. - М.: Мир, 1983. - 288 с.

13. Раменский Л. Г. Проблемы и методы изучения растительного покрова // Избранные работы. - Л.: Наука, 1971. - 334 с.

14. Хавезов И. Атомно-абсорбционный анализ / И. Хавезов, Д. Цалев. - Л.: Химия, 1983. - 144 с.

15. Юнатов А. А. Типы и содержание геоботанических исследований, выбор пробных площадей и заложение экологических профилей // Полевая геоботаника. - М.-Л.: Изд-во АН CCCP, 1964. - T. 3. - C. 9-36.

16. Jakubas D. Factors affecting the breeding success of the grey heron (Ardea cinerea) in northern Poland // Journal of Ornithology. - 2004. - Vol. 146, N 1. - P. 27-33.

17. Jakubas D. Diet composition and food consumption of the gray heron (Ardea cinerea) from breeding colonies in northern Poland / D. Jakubas, A. Mioduszewska // European Journal of Wildlife Research. - 2005. - Vol. 51, N 3. - P. 191-198.

Надійшла до редколегії 03.03.2006 